\title{
Zmienność liczby dni zimnych, chłodnych, ciepłych, gorących i upalnych w Polsce w okresie kwiecień-wrzesień
}

\author{
Variability in the numbers of cold, cool, warm, hot, \\ and very hot days in Poland in the April-September period
}

\section{CZESŁAW KOŹMIŃSKI}

Katedra Turystyki, Uniwersytet Szczeciński, 71-415 Szczecin, ul. Wąska 13;

klimet@univ.szczecin.pl

\section{BOŻENA MICHALSKA}

Zakład Meteorologii i Klimatologii, Zachodniopomorski Uniwersytet Technologiczny, 71-459 Szczecin, ul. Papieża Pawła VI, 3; bozena.michalska@zut.edu.pl

Zarys treści. W pracy wykorzystano dane o maksymalnej dobowej temperaturze powietrza w półroczu ciepłym (kwiecień-wrzesień) z 38 stacji meteorologicznych IMGW za lata 1986-2009. Opracowano liczbę dni charakterystycznych tj.: zimnych $\left(t_{\max } \leq 10,0^{\circ} \mathrm{C}\right)$, chłodnych $\left(t_{\max } 10,1-15,0^{\circ} \mathrm{C}\right)$, ciepłych $\left(t_{\max } 18,1-23,0^{\circ} \mathrm{C}\right)$, gorących $\left(t_{\max } 25,1-30,0{ }^{\circ} \mathrm{C}\right)$ i upalnych $\left(t_{\max }>30,0^{\circ} \mathrm{C}\right)$, podając średnią i maksymalną liczbę dni, tendencje zmian $\mathrm{w}$ wieloleciu oraz procentowy ich udział w ogólnej liczbie dni latem (czerwiec-sierpień) i w całym półroczu ciepłym (kwiecień-wrzesień). W przypadku dni upalnych obliczono najwcześniejsze wiosną i najpóźniejsze latem terminy występowania, określono ciągi dni o różnym czasie trwania, a także minimalną temperaturę $\left(\geq 20,0^{\circ} \mathrm{C}\right)$, która zwiększa uciążliwość fal upałów. Dni charakterystyczne opracowano w układzie zarówno czasowym, jak i przestrzennym. Dokonana analiza częstości występowania trzydniowych i dłuższych fal upałów oraz procentowy udział liczby dni upalnych w ogólnej liczbie dni w lecie dały podstawę do wydzielenia na terenie kraju trzech stref uciążliwości upałów dla organizmu człowieka.

Słowa kluczowe: dni charakterystyczne termicznie, trendy zmian, rozkład czasowy i przestrzenny, fale upałów, strefy uciążliwości.

\section{Wstęp}

Jednym z kryteriów oceny bioklimatu danego obszaru lub miejscowości na potrzeby rekreacji i turystyki są warunki termiczne powietrza, zwłaszcza występowanie dni zimnych i chłodnych, komfortowych, gorących i upalnych. W sezonie letnim zarówno chłodne jak i upalne dni, a przy intensywnym napromieniowaniu słonecznym także dni gorące, mogą być wysoce uciążliwe dla osób przebywających na otwartej przestrzeni (Błażejczyk, 2004; Cegnar i Matzarakis, 2004; 
Kozłowska-Szczęsna i inni, 2004). Dlatego wymienione dni charakterystyczne są często przedmiotem opracowań wykonanych dla różnych regionów (Koźmiński i Michalska, 2010; Piotrowicz, 2007) i całego kraju (Cebulak i Limanówka, 2007; Kuchcik, 2006; Ustrnul i Czekierda, 2002).

W badaniach uwzględniono głównie wyniki pomiarów temperatury powietrza ze stacji I rzędu IMGW położonych poza obszarami miast, w których, w zależności od ich wielkości (liczby ludności) i struktury zabudowy rzeczywista maksymalna temperatura powietrza może być wyższa o kilka stopni, co zwiększa uciążliwość życia ich mieszkańców. Od wielu lat zwiększa się liczba meteoropatów, uwrażliwionych na zmiany pogody, zwłaszcza w większych aglomeracjach, w tym i na temperaturę powietrza poniżej i powyżej termoneutralnego przedziału 18-23 ${ }^{\circ} \mathrm{C}$ (Błażejczyk, 2004; Bogucki i inni, 1999; Kozłowska-Szczęsna i inni, 2004). Wysoka temperatura maksymalna powietrza nie tylko wpływa na odczuwalność cieplną, ale także wyzwala szereg niekorzystnych reakcji w organizmie człowieka, na przykład obniża ciśnienie krwi, zwiększa częstość tętna, powoduje spadek aktywności itd. (Bogucki i inni, 1999). Szczególnie uciążliwa jest maksymalna temperatura powyżej $30^{\circ} \mathrm{C}$ przez kilka kolejnych dni, stając się nawet przyczyną zgonów (Matzarakis i Mayer, 1991; Brunetti i inni, 2000; Twardosz, 2009). Fala upałów, która dotknęła w 2003 r. głównie Francję, Niemcy, Hiszpanię, Włochy i Wielką Brytanię, pochłonęła około 35 tysięcy ofiar (Kuchcik, 2006).

Celem opracowania jest ocena czasowego i przestrzennego rozkładu dni zimnych, chłodnych, ciepłych, gorących i upalnych oraz terminów występowania dni upalnych na terenie Polski. Dokonano analizy zmian dni charakterystycznych w wieloleciu w półroczu kwiecień-wrzesień, ze szczególnym uwzględnieniem okresu letniego (czerwiec-sierpień), a także wydzielono strefy o różnej uciążliwości ze względu na występowanie fal upałów.

\section{Materiały i metody}

W pracy wykorzystano maksymalne dobowe wartości temperatury powietrza z okresu kwiecień-wrzesień z 38 stacji I rzędu IMGW za lata 1986-2009. W klimatologii i bioklimatologii do oceny warunków termicznych powietrza przyjmuje się różne kryteria (Błażejczyk, 2004; Kossowska-Cezak i inni, 2000; KozłowskaSzczęsna i inni, 1997). Na przykład za dzień gorący uznaje się taki, w którym maksymalna temperatura przekracza $25^{\circ} \mathrm{C}$, a za bardzo gorący (upalny) - taki, w którym ta temperatura przekracza $30^{\circ} \mathrm{C}$. Jest tu pewna niespójność, gdyż w dniach zaliczanych do gorących mogą się również znaleźć wartości temperatury powyżej $30^{\circ} \mathrm{C}$, co kwalifikuje ten dzień jako upalny. Z kolei V. Boksa i B. Boguckij (1966) posługując się średnią dobową temperaturą dokonali podziału termicznego na 5 klas o zakresie 5 stopni każda, przypisując tym przedziałom określone odczucia cieplne - od zimno $\left(\leq 10^{\circ} \mathrm{C}\right)$ do gorąco $\left(25,1-30,0^{\circ} \mathrm{C}\right)$. W klimatycznych warunkach 
Polski, przy średnich dobowych wartościach temperatury $25,1-30,0{ }^{\circ} \mathrm{C}$ z reguły notuje się maksymalną temperaturę powyżej $30^{\circ} \mathrm{C}$, a nawet powyżej $35^{\circ} \mathrm{C}$ i wówczas taki dzień, według wcześniej podanej klasyfikacji należałoby uznać za upalny. W niniejszej pracy przyjęto zatem klasyfikację opartą na maksymalnej temperaturze powietrza, wywierającej duży wpływ na odczucia cieplne organizmu człowieka. Należy podkreślić, że wartości maksymalnej temperatury powietrza podawane są w codziennych prognozach pogody. W bioklimatologii uznaje się średnią dobową temperaturę powietrza w przedziale $18,1-23,0{ }^{\circ} \mathrm{C}$ za komfortową; wówczas zostaje zachowana równowaga bilansu cieplnego organizmu człowieka. Aby ujednolicić kryteria podziału analizowanych dni charakterystycznych, wspomniany wyżej przedział temperatury $\left(18,1-23,0{ }^{\circ} \mathrm{C}\right)$ wyróżniono w opracowaniu na podstawie maksymalnej temperatury powietrza, określając te dni jako ciepłe. W efekcie przyjęto następujący podział dni charakterystycznych w półroczu ciepłym:

\begin{tabular}{cl}
$t_{\max }{ }^{\circ} \mathrm{C}$ & dni charakterystyczne \\
\hline$\leq 10$ & zimne \\
$10,1-15,0$ & chłodne \\
$18,1-23,0$ & ciepłe \\
$25,1-30,0$ & gorące \\
$>30,0$ & upalne
\end{tabular}

W wymienionych przedziałach temperatury określono tendencje zmian liczby dni charakterystycznych, w latach 1986-2009 oraz przestrzenny ich rozkład w półroczu ciepłym (kwiecień-wrzesień) i w okresie letnim (czerwiecsierpień). Analizowano również procentowy udział dni charakterystycznych w ogólnej liczbie dni w okresie letnim oraz dni upalnych, w których temperatura minimalna była $\geq 20^{\circ} \mathrm{C}$ (tzw. noce gorące). Obliczono daty początku i końca okresu występowania dni upalnych oraz ich intensywność, rozumianą jako średnią wartość maksymalnej temperatury powyżej $30^{\circ} \mathrm{C}$. Wyznaczono okresy o największej częstości dni gorących i upalnych w ciepłej połowie roku, a także występowanie fal upałów trwających co najmniej 3 dni, w których maksymalna temperatura powietrza była wyższa od $30^{\circ} \mathrm{C}$. Uwzględniając występowanie tak zdefiniowanych fal upałów oraz dodatkowo procentowy udział dni upalnych w ogólnej liczbie dni w okresie czerwiec-sierpień, a także częstość (\%) lat z temperaturą maksymalną $>30,0^{\circ} \mathrm{C}$, wydzielono na terenie kraju 3 strefy uciążliwości.

W analizach pominięto obszary górskie, z uwagi na małą liczbę dostępnych stacji, przy bardzo dużym zróżnicowaniu fizjograficznym terenu. 


\section{Analiza wyników}

W rozpatrywanych latach 1986-2009 zaznacza się w półroczu ciepłym dodatni, wysoce istotny statystycznie w Polsce południowej i środkowo-wschodniej, a istotny na pozostałym obszarze kraju (poza rejonem Łeby i Ustki) trend liczby dni gorących $\left(t_{\max } 25,1-30,0^{\circ} \mathrm{C}\right)$. W odniesieniu do dni zimnych $\left(t_{\max } \leq 10,0^{\circ} \mathrm{C}\right)$, również wysoce istotny, ale ujemny trend obserwuje się na całym obszarze kraju, poza jego południowo-wschodnią i południową częścią, gdzie spadek liczby tych dni jest istotny (na poziomie co najmniej 0,05). Szczególnie wyraźne zmniejszanie się liczby dni z temperaturą maksymalną $\leq 10,0^{\circ} \mathrm{C}$ obserwowane jest w północnej części kraju (wartości współczynników korelacji $r$ powyżej -0,6), ale za to mniej wyraźny jest tu spadek liczby dni chłodnych $\left(t_{\max } 10,1-15,0{ }^{\circ} \mathrm{C}\right)$.
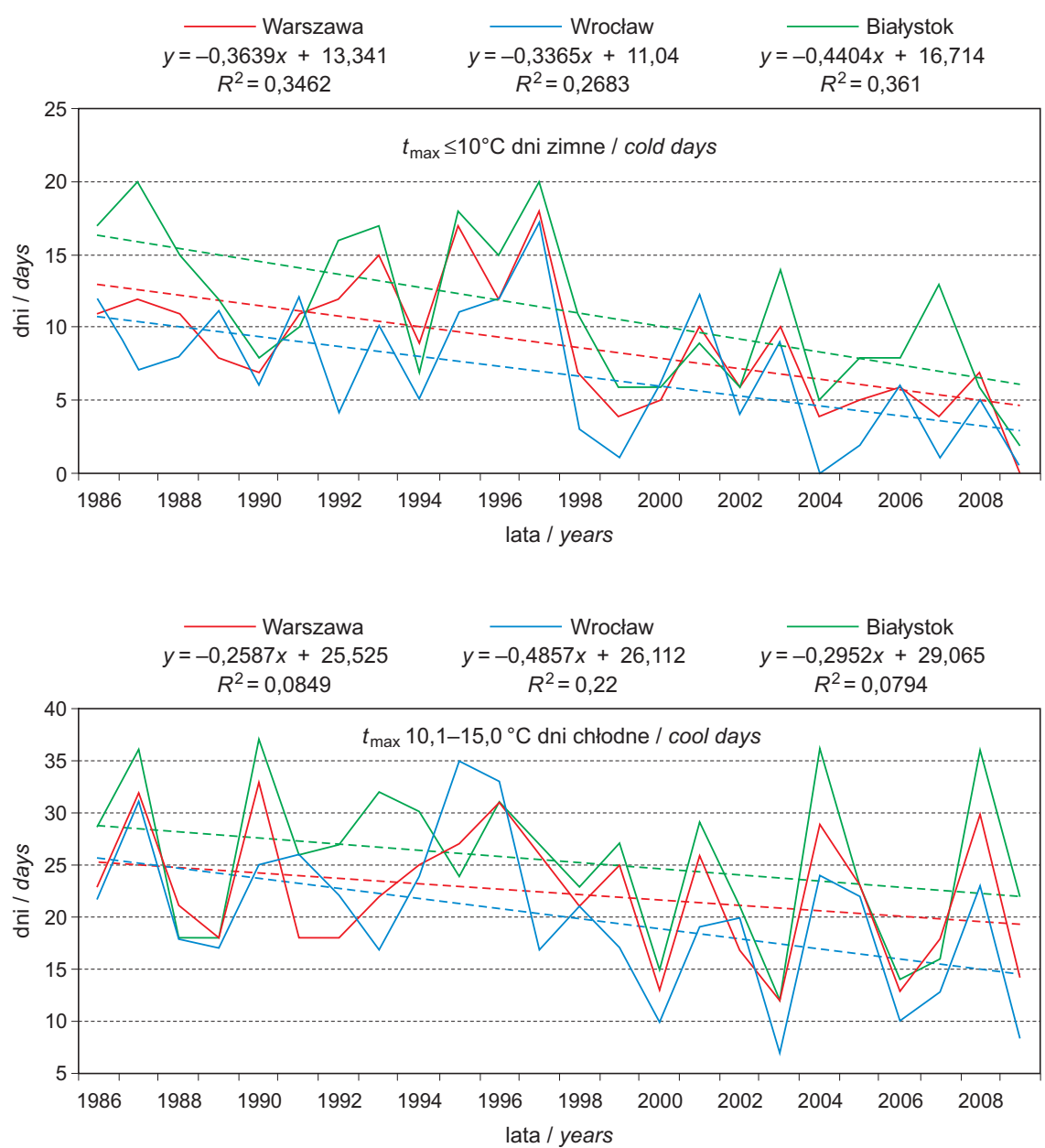

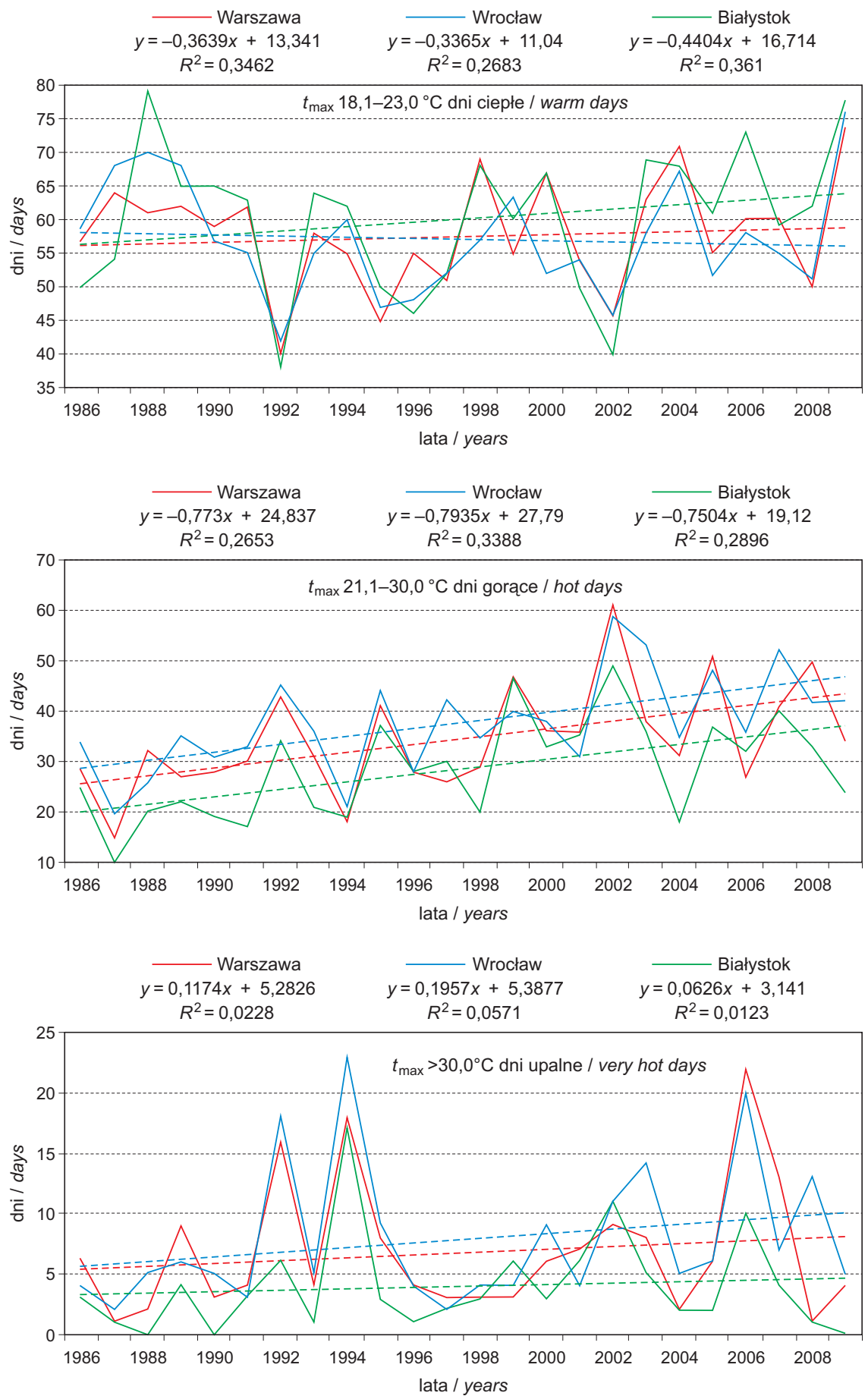

Ryc. 1. Przebieg liczby dni zimnych, chłodnych, ciepłych, gorących i upalnych wraz z trendem w okresie kwiecień-wrzesień w latach 1986-2009 na stacjach: Warszawa, Wrocław i Białystok

The course of cold, cool, warm, hot and very hot days along with the trends noted for them in the April-September period at the stations in Warsaw, Wrocław and Białystok over the years 1986-2009 
Wprawdzie współczynniki korelacji $r$ są ujemne, ale ich wartości wahają się, w zależności od regionu, od $-0,11$ do $-0,38$, a więc są nieistotne statystycznie. W Polsce zachodniej i południowej, podobnie jak w przypadku dni zimnych, zmniejszanie się liczby dni chłodnych jest istotne statystycznie (ryc. 1). Z przebiegu czasowego liczby dni ciepłych $\left(t_{\max } 18,1-23,0{ }^{\circ} \mathrm{C}\right)$ w latach $1986-2009$ nie występują żadne istotne zmiany na terenie kraju, poza strefą wybrzeża, gdzie zauważa się istotny i wysoce istotny wzrost tych dni (wartości $r$ od 0,49 do 0,59$)$. W przypadku dni upalnych $\left(t_{\max }>30,0^{\circ} \mathrm{C}\right)$ niewielką tendencję wzrostową obserwuje się jedynie w centralnej Wielkopolsce, chociaż E. Cebulak i D. Limanówka (2007) wskazują na tendencję rosnącą liczby tych dni w latach 1951-2005 na znacznym obszarze kraju, a B. Michalska i A. Mąkosza (2007) stwierdzają istotny, dodatni trend dni upalnych na Nizinie Szczecińskiej.

W okresie kwiecień-wrzesień średnia liczba dni zimnych waha się od poniżej 8 na Dolnym Śląsku i w Kotlinie Sandomierskiej do ponad 18 w północnej części wybrzeża (ryc. 2). Szczególnie duże zróżnicowanie liczby tych dni obserwuje się na Pomorzu (od 10 do 18) i Pojezierzu Mazurskim (od 10 do 16). Dni zimne występują głównie w kwietniu oraz w maju i we wrześniu, a sporadycznie w czerwcu i sierpniu (tab. 1). Przestrzenne zróżnicowanie średniej liczby dni chłodnych jest mniej wyraźne niż wyżej opisanych dni zimnych, ale ich liczba jest od dwóch do trzech razy większa, bowiem w najcieplejszych regionach Polski - na Nizinie Śląskiej i w Kotlinie Sandomierskiej notuje się tych dni poniżej 22 w okresie kwiecień-wrzesień, a na północy kraju - ponad 30. Przestrzenny rozkład średniej liczby dni ciepłych jest odmienny niż zimnych i chłodnych, gdyż izarytmy biegną raczej południkowo (ryc. 2). Najmniej dni ciepłych (poniżej 54) występuje w rejonie Raciborza; liczba ta zwiększa się stopniowo ku wschodowi (ponad 60 dni) i północnemu zachodowi (ponad 62). Liczba dni gorących kształtuje się średnio od poniżej 15 w strefie wybrzeża Bałtyku do 35 na większości obszaru kraju, gdzie jednocześnie notuje się dużą liczbę godzin ze słońcem (Koźmiński i Michalska, 2005). Najwięcej dni gorących - nawet do 39 - notuje się na Nizinie Śląskiej (tab. 1). Przestrzenny rozkład średniej liczby dni upalnych jest zbliżony do wyżej opisanego, ale ich wartości wynoszą od około 3 w pasie północnym do około 7 w Wielkopolsce, na Nizinie Śląskiej i w Kotlinie Sandomierskiej (ryc. 2). W środkowej i południowej Polsce dni upalne w okresie 1986-2009 występowały co roku, a na pozostałym obszarze ich częstość wyniosła od około 80\% w rejonie Łeby i Helu do około 90\% na Pojezierzu Pomorskim i Pojezierzu Mazurskim.

Spośród analizowanych 24 lat, pod względem liczby dni gorących wyróżnia się rok 2002, a dni upalnych 2006 (ryc. 3). Niemal w całej Polsce, poza częścią zachodnią, liczba dni gorących kształtowała się od 50 do 60, a w pasie równoleżnikowym od Opola po Rzeszów przekroczyła nawet 60 . Najmniej dni gorących było na Pomorzu - 30-40 i na wybrzeżu - poniżej 30. Z kolei dni upalne najliczniej wystąiły w 2006 r. w Polsce centralnej - ich liczba przekroczyła 20, a lokalnie 
Tabela 1. Średnia (śr) i najwyższa (max) w okresie kwiecień-wrzesień liczba dni z maksymalną temperaturą powietrza według przyjętych przedziałów dla wybranych stacji. Lata 1986-2009

The mean and greatest (max) numbers of days at selected stations with maximum air temperatures qualifying for inclusion in the different intervals or categories recognised. Years 1986-2009

\begin{tabular}{|c|c|c|c|c|c|c|c|c|c|c|c|c|c|c|c|c|c|c|c|c|c|c|c|c|c|c|c|c|c|c|c|}
\hline \multirow{2}{*}{$\begin{array}{c}\text { Stacja } \\
\text { Station }\end{array}$} & \multirow{2}{*}{$\begin{array}{c}\begin{array}{c}\text { Liczba } \\
\text { dni }\end{array} \\
\begin{array}{c}\text { Number } \\
\text { of days }\end{array}\end{array}$} & \multicolumn{6}{|c|}{$\leq 10,0^{\circ} \mathrm{C}$} & \multicolumn{6}{|c|}{$10,1-15,0^{\circ} \mathrm{C}$} & \multicolumn{6}{|c|}{$18,1-23,0{ }^{\circ} \mathrm{C}$} & \multicolumn{6}{|c|}{$25,1-30,0{ }^{\circ} \mathrm{C}$} & \multicolumn{6}{|c|}{$>30,0^{\circ} \mathrm{C}$} \\
\hline & & IV & $\mathrm{V}$ & VI & VII & VII & IX & IV & V & VI & VII & VIII & IX & IV & V & VI & VII & VIII & IX & IV & V & VI & VII & VIII & IX & IV & V & VI & VII & VIII & IX \\
\hline Białystok & $\begin{array}{l}\text { śr/mean } \\
\max \end{array}$ & $\begin{array}{l}9,6 \\
20\end{array}$ & $\begin{array}{c}0,5 \\
4\end{array}$ & - & - & - & $\begin{array}{c}1,1 \\
6\end{array}$ & $\begin{array}{l}9,5 \\
15\end{array}$ & $\begin{array}{l}6,1 \\
15\end{array}$ & - & - & - & $\begin{array}{l}7,7 \\
20\end{array}$ & $\begin{array}{c}4,0 \\
7\end{array}$ & $\begin{array}{c}10,8 \\
17\end{array}$ & $\begin{array}{c}13,0 \\
18\end{array}$ & $\begin{array}{c}10,8 \\
19\end{array}$ & $\begin{array}{c}12,4 \\
23\end{array}$ & $\begin{array}{l}9,2 \\
22\end{array}$ & $\begin{array}{c}0,6 \\
6\end{array}$ & $\begin{array}{c}2,9 \\
9\end{array}$ & $\begin{array}{c}6,0 \\
13\end{array}$ & $\begin{array}{c}9,3 \\
21\end{array}$ & $\begin{array}{c}8,5 \\
24\end{array}$ & $\begin{array}{c}1,3 \\
5\end{array}$ & - & $\begin{array}{c}0,1 \\
1\end{array}$ & $\begin{array}{c}0,5 \\
3\end{array}$ & $\begin{array}{c}2,3 \\
12\end{array}$ & $\begin{array}{c}1,0 \\
5\end{array}$ & - \\
\hline $\begin{array}{l}\text { Gorzów } \\
\text { Wlkp. }\end{array}$ & $\begin{array}{l}\text { śr/mean } \\
\max \end{array}$ & $\begin{array}{l}7,5 \\
17\end{array}$ & $\begin{array}{c}0,7 \\
6\end{array}$ & - & - & - & $\begin{array}{c}0,0 \\
1\end{array}$ & $\begin{array}{c}9,6 \\
16\end{array}$ & $\begin{array}{c}5,4 \\
18\end{array}$ & - & - & - & $\begin{array}{l}5,8 \\
17\end{array}$ & $\begin{array}{l}5,1 \\
10\end{array}$ & $\begin{array}{c}11,2 \\
18\end{array}$ & $\begin{array}{c}12,7 \\
19\end{array}$ & $\begin{array}{c}11,2 \\
23\end{array}$ & $\begin{array}{c}11,3 \\
18\end{array}$ & $\begin{array}{c}10,5 \\
17\end{array}$ & $\begin{array}{c}0,9 \\
6\end{array}$ & $\begin{array}{c}3,6 \\
10\end{array}$ & $\begin{array}{l}6,0 \\
18\end{array}$ & $\begin{array}{l}8,8 \\
17\end{array}$ & $\begin{array}{l}9,9 \\
23\end{array}$ & $\begin{array}{c}2,3 \\
9\end{array}$ & - & $\begin{array}{c}0,1 \\
1\end{array}$ & $\begin{array}{c}1,1 \\
5\end{array}$ & $\begin{array}{c}3,2 \\
19\end{array}$ & $\begin{array}{c}1,8 \\
7\end{array}$ & - \\
\hline Kłodzko & $\begin{array}{l}\text { śr/mean } \\
\text { max }\end{array}$ & $\begin{array}{l}8,5 \\
17\end{array}$ & $\begin{array}{l}1,2 \\
7\end{array}$ & $\begin{array}{c}0,1 \\
1\end{array}$ & - & $\begin{array}{c}0,0 \\
1\end{array}$ & $\begin{array}{c}0,6 \\
8\end{array}$ & $\begin{array}{c}10,3 \\
17\end{array}$ & $\begin{array}{l}6,8 \\
15\end{array}$ & $\begin{array}{c}2,7 \\
7\end{array}$ & - & $\begin{array}{c}1,0 \\
4\end{array}$ & $\begin{array}{l}7,9 \\
18\end{array}$ & $\begin{array}{l}4,6 \\
14\end{array}$ & $\begin{array}{c}11,5 \\
24\end{array}$ & $\begin{array}{c}12,4 \\
23\end{array}$ & $\begin{array}{c}11,5 \\
16\end{array}$ & $\begin{array}{c}10,0 \\
16\end{array}$ & $\begin{array}{c}10,1 \\
22\end{array}$ & $\begin{array}{c}0,1 \\
2\end{array}$ & $\begin{array}{c}1,9 \\
6\end{array}$ & $\begin{array}{l}5,0 \\
12\end{array}$ & $\begin{array}{c}8,3 \\
19\end{array}$ & $\begin{array}{l}8,7 \\
18\end{array}$ & $\begin{array}{c}1,0 \\
4\end{array}$ & - & $\begin{array}{c}0,1 \\
2\end{array}$ & $\begin{array}{c}0,3 \\
3\end{array}$ & $\begin{array}{c}1,4 \\
8\end{array}$ & $\begin{array}{l}1,8 \\
11\end{array}$ & $\begin{array}{c}0,0 \\
1\end{array}$ \\
\hline Kraków & $\begin{array}{l}\text { śr/mean } \\
\max \end{array}$ & $\begin{array}{l}7,0 \\
18\end{array}$ & $\begin{array}{c}0,6 \\
4\end{array}$ & $\begin{array}{c}0,1 \\
1\end{array}$ & - & - & $\begin{array}{l}1,0 \\
10\end{array}$ & $\begin{array}{c}9,5 \\
16\end{array}$ & $\begin{array}{l}4,5 \\
12\end{array}$ & $\begin{array}{c}1,2 \\
5\end{array}$ & - & - & $\begin{array}{l}5,7 \\
13\end{array}$ & $\begin{array}{l}5,7 \\
11\end{array}$ & $\begin{array}{c}10,7 \\
20\end{array}$ & $\begin{array}{c}11,3 \\
21\end{array}$ & $\begin{array}{c}9,3 \\
17\end{array}$ & $\begin{array}{c}9,8 \\
18\end{array}$ & $\begin{array}{c}10,5 \\
17\end{array}$ & $\begin{array}{c}0,5 \\
4\end{array}$ & $\begin{array}{c}3,3 \\
10\end{array}$ & $\begin{array}{c}6,9 \\
16\end{array}$ & $\begin{array}{c}10,2 \\
18\end{array}$ & $\begin{array}{c}10,1 \\
23\end{array}$ & $\begin{array}{c}2,1 \\
7\end{array}$ & - & $\begin{array}{c}0,3 \\
4\end{array}$ & $\begin{array}{c}1,0 \\
3\end{array}$ & $\begin{array}{c}3,2 \\
17\end{array}$ & $\begin{array}{c}2,3 \\
13\end{array}$ & - \\
\hline Lublin & $\begin{array}{l}\text { śr/mean } \\
\max \end{array}$ & $\begin{array}{c}8,8 \\
19\end{array}$ & $\begin{array}{c}0,5 \\
2\end{array}$ & $\begin{array}{c}0,0 \\
1\end{array}$ & - & $\begin{array}{c}0,0 \\
1\end{array}$ & $\begin{array}{c}1,2 \\
8\end{array}$ & $\begin{array}{c}10,4 \\
19\end{array}$ & $\begin{array}{l}6,5 \\
13\end{array}$ & $\begin{array}{c}1,5 \\
5\end{array}$ & - & $\begin{array}{c}0,6 \\
4\end{array}$ & $\begin{array}{l}7,4 \\
20\end{array}$ & $\begin{array}{l}4,8 \\
11\end{array}$ & $\begin{array}{c}11,5 \\
18\end{array}$ & $\begin{array}{c}12,3 \\
23\end{array}$ & $\begin{array}{c}10,5 \\
19\end{array}$ & $\begin{array}{c}11,5 \\
19\end{array}$ & $\begin{array}{c}10,0 \\
21\end{array}$ & $\begin{array}{c}0,1 \\
1\end{array}$ & $\begin{array}{c}2,5 \\
10\end{array}$ & $\begin{array}{l}6,0 \\
12\end{array}$ & $\begin{array}{l}9,6 \\
15\end{array}$ & $\begin{array}{l}8,8 \\
20\end{array}$ & $\begin{array}{c}1,6 \\
6\end{array}$ & - & $\begin{array}{c}0,1 \\
2\end{array}$ & $\begin{array}{c}0,3 \\
2\end{array}$ & $\begin{array}{l}2,4 \\
12\end{array}$ & $\begin{array}{c}1,7 \\
8\end{array}$ & - \\
\hline Olsztyn & $\begin{array}{l}\text { śr/mean } \\
\text { max }\end{array}$ & $\begin{array}{c}10,8 \\
19\end{array}$ & $\begin{array}{c}0,8 \\
5\end{array}$ & - & - & - & $\begin{array}{c}0,8 \\
4\end{array}$ & $\begin{array}{l}9,2 \\
15\end{array}$ & $\begin{array}{l}7,7 \\
17\end{array}$ & - & - & - & $\begin{array}{l}8,4 \\
23\end{array}$ & $\begin{array}{c}3,4 \\
7\end{array}$ & $\begin{array}{c}10,2 \\
15\end{array}$ & $\begin{array}{c}12,9 \\
20\end{array}$ & $\begin{array}{c}12,0 \\
21\end{array}$ & $\begin{array}{c}13,5 \\
21\end{array}$ & $\begin{array}{l}9,2 \\
20\end{array}$ & $\begin{array}{c}0,6 \\
5\end{array}$ & $\begin{array}{c}2,8 \\
11\end{array}$ & $\begin{array}{l}4,9 \\
11\end{array}$ & $\begin{array}{l}7,5 \\
16\end{array}$ & $\begin{array}{l}7,5 \\
25\end{array}$ & $\begin{array}{c}0,9 \\
5\end{array}$ & - & $\begin{array}{c}0,1 \\
1\end{array}$ & $\begin{array}{c}0,4 \\
4\end{array}$ & $\begin{array}{l}2,2 \\
10\end{array}$ & $\begin{array}{c}1,1 \\
4\end{array}$ & - \\
\hline Poznań & $\begin{array}{l}\text { śr/mean } \\
\max \end{array}$ & $\begin{array}{c}6,8 \\
17\end{array}$ & $\begin{array}{c}0,6 \\
5\end{array}$ & $\begin{array}{c}0,0 \\
1\end{array}$ & - & - & $\begin{array}{c}0,1 \\
1\end{array}$ & $\begin{array}{c}10,3 \\
19\end{array}$ & $\begin{array}{l}4,5 \\
12\end{array}$ & $\begin{array}{c}1,2 \\
4\end{array}$ & - & - & $\begin{array}{c}5,2 \\
16\end{array}$ & $\begin{array}{c}4,9 \\
11\end{array}$ & $\begin{array}{c}11,4 \\
19\end{array}$ & $\begin{array}{c}12,0 \\
20\end{array}$ & $\begin{array}{c}9,8 \\
19\end{array}$ & $\begin{array}{l}9,7 \\
18\end{array}$ & $\begin{array}{c}10,2 \\
16\end{array}$ & $\begin{array}{c}0,9 \\
7\end{array}$ & $\begin{array}{c}3,5 \\
9\end{array}$ & $\begin{array}{c}6,8 \\
18\end{array}$ & $\begin{array}{c}9,6 \\
17\end{array}$ & $\begin{array}{c}10,6 \\
23\end{array}$ & $\begin{array}{c}2,5 \\
10\end{array}$ & - & $\begin{array}{c}0,3 \\
2\end{array}$ & $\begin{array}{c}1,3 \\
5\end{array}$ & $\begin{array}{l}3,9 \\
21\end{array}$ & $\begin{array}{c}2,5 \\
8\end{array}$ & $\begin{array}{c}0,0 \\
1\end{array}$ \\
\hline Rzeszów & $\begin{array}{l}\text { srr/mean } \\
\max \end{array}$ & $\begin{array}{l}6,4 \\
17\end{array}$ & $\begin{array}{c}0,4 \\
2\end{array}$ & $\begin{array}{c}0,0 \\
1\end{array}$ & - & - & $\begin{array}{c}0,8 \\
5\end{array}$ & $\begin{array}{c}10,0 \\
14\end{array}$ & $\begin{array}{l}4,0 \\
13\end{array}$ & $\begin{array}{c}0,8 \\
3\end{array}$ & - & - & $\begin{array}{l}5,8 \\
18\end{array}$ & $\begin{array}{c}5,8 \\
9\end{array}$ & $\begin{array}{c}11,9 \\
19\end{array}$ & $\begin{array}{c}11,5 \\
18\end{array}$ & $\begin{array}{c}8,9 \\
18\end{array}$ & $\begin{array}{l}9,3 \\
20\end{array}$ & $\begin{array}{c}11,0 \\
17\end{array}$ & $\begin{array}{c}0,4 \\
3\end{array}$ & $\begin{array}{l}3,5 \\
12\end{array}$ & $\begin{array}{l}7,9 \\
15\end{array}$ & $\begin{array}{c}11,5 \\
21\end{array}$ & $\begin{array}{c}11,3 \\
21\end{array}$ & $\begin{array}{c}2,4 \\
8\end{array}$ & - & $\begin{array}{c}0,3 \\
3\end{array}$ & $\begin{array}{c}1,2 \\
7\end{array}$ & $\begin{array}{c}3,6 \\
14\end{array}$ & $\begin{array}{r}2,5 \\
12\end{array}$ & $\begin{array}{c}0,0 \\
1\end{array}$ \\
\hline Suwałki & $\begin{array}{l}\text { śr/mean } \\
\max \end{array}$ & $\begin{array}{c}11,3 \\
21\end{array}$ & $\begin{array}{c}1,2 \\
6\end{array}$ & $\begin{array}{c}0,0 \\
1\end{array}$ & - & - & $\begin{array}{c}1,0 \\
6\end{array}$ & $\begin{array}{l}9,3 \\
17\end{array}$ & $\begin{array}{l}7,5 \\
17\end{array}$ & $\begin{array}{c}2,0 \\
5\end{array}$ & - & - & $\begin{array}{l}9,3 \\
22\end{array}$ & $\begin{array}{c}3,3 \\
7\end{array}$ & $\begin{array}{l}9,5 \\
15\end{array}$ & $\begin{array}{c}13,0 \\
21\end{array}$ & $\begin{array}{c}13,0 \\
22\end{array}$ & $\begin{array}{c}13,6 \\
21\end{array}$ & $\begin{array}{l}9,0 \\
22\end{array}$ & $\begin{array}{c}0,4 \\
5\end{array}$ & $\begin{array}{c}2,5 \\
8\end{array}$ & $\begin{array}{l}4,2 \\
12\end{array}$ & $\begin{array}{l}7,7 \\
16\end{array}$ & $\begin{array}{l}7,8 \\
26\end{array}$ & $\begin{array}{c}1,0 \\
6\end{array}$ & - & $\begin{array}{c}0,0 \\
1\end{array}$ & $\begin{array}{c}0,3 \\
2\end{array}$ & $\begin{array}{c}1,8 \\
8\end{array}$ & $\begin{array}{c}0,8 \\
5\end{array}$ & - \\
\hline Szczecin & $\begin{array}{l}\text { sr } / \text { mean } \\
\max \end{array}$ & $\begin{array}{l}7,5 \\
15\end{array}$ & $\begin{array}{c}0,6 \\
6\end{array}$ & - & - & - & $\begin{array}{c}0,0 \\
1\end{array}$ & $\begin{array}{c}10,4 \\
17\end{array}$ & $\begin{array}{c}5,8 \\
16\end{array}$ & - & - & - & $\begin{array}{l}5,0 \\
16\end{array}$ & $\begin{array}{l}4,5 \\
13\end{array}$ & $\begin{array}{c}11,1 \\
20\end{array}$ & $\begin{array}{c}13,5 \\
22\end{array}$ & $\begin{array}{c}12,5 \\
20\end{array}$ & $\begin{array}{c}12,8 \\
18\end{array}$ & $\begin{array}{c}11,2 \\
22\end{array}$ & $\begin{array}{c}0,9 \\
7\end{array}$ & $\begin{array}{c}3,3 \\
11\end{array}$ & $\begin{array}{l}5,2 \\
18\end{array}$ & $\begin{array}{l}8,7 \\
19\end{array}$ & $\begin{array}{l}8,6 \\
21\end{array}$ & $\begin{array}{c}1,9 \\
8\end{array}$ & _- & $\begin{array}{c}0,2 \\
1\end{array}$ & $\begin{array}{c}0,8 \\
4\end{array}$ & $\begin{array}{c}2,8 \\
16\end{array}$ & $\begin{array}{c}1,5 \\
7\end{array}$ & $\begin{array}{c}0,0 \\
1\end{array}$ \\
\hline Szczecinek & $\begin{array}{l}\text { śr/mean } \\
\max \end{array}$ & $\begin{array}{l}9,7 \\
19\end{array}$ & $\begin{array}{c}1,7 \\
9\end{array}$ & - & - & - & $\begin{array}{c}0,5 \\
2\end{array}$ & $\begin{array}{l}8,5 \\
15\end{array}$ & $\begin{array}{l}7,0 \\
17\end{array}$ & - & - & - & $\begin{array}{l}7,7 \\
23\end{array}$ & $\begin{array}{l}4,2 \\
10\end{array}$ & $\begin{array}{l}9,8 \\
18\end{array}$ & $\begin{array}{c}13,5 \\
24\end{array}$ & $\begin{array}{c}12,0 \\
22\end{array}$ & $\begin{array}{c}12,4 \\
19\end{array}$ & $\begin{array}{l}9,5 \\
17\end{array}$ & $\begin{array}{c}0,7 \\
7\end{array}$ & $\begin{array}{c}2,7 \\
9\end{array}$ & $\begin{array}{c}3,9 \\
12\end{array}$ & $\begin{array}{l}7,6 \\
15\end{array}$ & $\begin{array}{l}7,4 \\
17\end{array}$ & $\begin{array}{c}1,0 \\
6\end{array}$ & - & $\begin{array}{c}0,1 \\
2\end{array}$ & $\begin{array}{c}0,7 \\
5\end{array}$ & $\begin{array}{l}2,1 \\
12\end{array}$ & $\begin{array}{c}1,2 \\
6\end{array}$ & - \\
\hline Toruń & $\begin{array}{l}\text { śr/mean } \\
\max \end{array}$ & $\begin{array}{l}7,7 \\
17\end{array}$ & $\begin{array}{c}0,5 \\
6\end{array}$ & - & - & - & $\begin{array}{c}0,3 \\
3\end{array}$ & $\begin{array}{c}9,3 \\
17\end{array}$ & $\begin{array}{l}5,2 \\
14\end{array}$ & - & - & - & $\begin{array}{l}5,6 \\
14\end{array}$ & $\begin{array}{c}4,4 \\
9\end{array}$ & $\begin{array}{c}10,3 \\
17\end{array}$ & $\begin{array}{c}11,6 \\
18\end{array}$ & $\begin{array}{c}10,0 \\
19\end{array}$ & $\begin{array}{c}10,5 \\
19\end{array}$ & $\begin{array}{c}10,5 \\
19\end{array}$ & $\begin{array}{c}1,1 \\
8\end{array}$ & $\begin{array}{c}4,3 \\
14\end{array}$ & $\begin{array}{l}6,3 \\
14\end{array}$ & $\begin{array}{l}9,9 \\
16\end{array}$ & $\begin{array}{c}11,3 \\
25\end{array}$ & $\begin{array}{c}2,3 \\
11\end{array}$ & - & $\begin{array}{c}0,4 \\
2\end{array}$ & $\begin{array}{c}1,0 \\
6\end{array}$ & $\begin{array}{c}3,7 \\
17\end{array}$ & $\begin{array}{c}2,0 \\
7\end{array}$ & $\begin{array}{c}0,0 \\
1\end{array}$ \\
\hline Ustka & $\begin{array}{l}\text { śr/mean } \\
\max \end{array}$ & $\begin{array}{c}16,5 \\
25\end{array}$ & $\begin{array}{l}4,3 \\
15\end{array}$ & - & - & - & $\begin{array}{c}0,1 \\
2\end{array}$ & $\begin{array}{l}8,3 \\
15\end{array}$ & $\begin{array}{c}14,1 \\
22\end{array}$ & - & - & - & $\begin{array}{l}7,8 \\
27\end{array}$ & $\begin{array}{c}1,8 \\
5\end{array}$ & $\begin{array}{c}4,1 \\
7\end{array}$ & $\begin{array}{l}9,7 \\
24\end{array}$ & $\begin{array}{c}15,6 \\
26\end{array}$ & $\begin{array}{c}16,4 \\
25\end{array}$ & $\begin{array}{l}8,5 \\
21\end{array}$ & $\begin{array}{c}0,6 \\
5\end{array}$ & $\begin{array}{c}1,2 \\
4\end{array}$ & $\begin{array}{c}1,8 \\
7\end{array}$ & $\begin{array}{l}3,9 \\
22\end{array}$ & $\begin{array}{c}3,8 \\
14\end{array}$ & $\begin{array}{c}0,9 \\
6\end{array}$ & - & $\begin{array}{c}0,0 \\
1\end{array}$ & $\begin{array}{c}0,3 \\
2\end{array}$ & $\begin{array}{c}1,3 \\
4\end{array}$ & $\begin{array}{c}0,4 \\
2\end{array}$ & - \\
\hline Warszawa & $\begin{array}{l}\text { śr/mean } \\
\max \end{array}$ & $\begin{array}{l}8,1 \\
18\end{array}$ & $\begin{array}{c}0,4 \\
2\end{array}$ & - & - & - & $\begin{array}{c}0,3 \\
3\end{array}$ & $\begin{array}{c}10,1 \\
15\end{array}$ & $\begin{array}{l}4,8 \\
10\end{array}$ & - & - & - & $\begin{array}{l}6,1 \\
19\end{array}$ & $\begin{array}{l}4,5 \\
11\end{array}$ & $\begin{array}{c}11,0 \\
18\end{array}$ & $\begin{array}{c}11,7 \\
20\end{array}$ & $\begin{array}{l}9,6 \\
22\end{array}$ & $\begin{array}{c}10,8 \\
15\end{array}$ & $\begin{array}{c}9,8 \\
19\end{array}$ & $\begin{array}{c}0,9 \\
8\end{array}$ & $\begin{array}{c}3,8 \\
10\end{array}$ & $\begin{array}{l}7,1 \\
17\end{array}$ & $\begin{array}{c}10,8 \\
20\end{array}$ & $\begin{array}{c}10,3 \\
23\end{array}$ & $\begin{array}{c}1,7 \\
9\end{array}$ & - & $\begin{array}{c}0,3 \\
3\end{array}$ & $\begin{array}{c}1,2 \\
5\end{array}$ & $\begin{array}{c}3,4 \\
18\end{array}$ & $\begin{array}{l}1,8 \\
11\end{array}$ & $\begin{array}{c}0,0 \\
1\end{array}$ \\
\hline Wrocław & $\begin{array}{l}\text { śr/mean } \\
\max \end{array}$ & $\begin{array}{l}6,1 \\
16\end{array}$ & $\begin{array}{c}0,5 \\
5\end{array}$ & $\begin{array}{c}0,0 \\
1\end{array}$ & - & $\begin{array}{lll}- & & \\
-\end{array}$ & $\begin{array}{c}0,2 \\
3\end{array}$ & $\begin{array}{c}9,3 \\
17\end{array}$ & $\begin{array}{l}4,4 \\
11\end{array}$ & $\begin{array}{c}1,1 \\
4\end{array}$ & - & - & $\begin{array}{l}5,0 \\
15\end{array}$ & $\begin{array}{l}5,7 \\
14\end{array}$ & $\begin{array}{c}11,4 \\
19\end{array}$ & $\begin{array}{c}11,5 \\
19\end{array}$ & $\begin{array}{l}9,4 \\
17\end{array}$ & $\begin{array}{l}8,9 \\
18\end{array}$ & $\begin{array}{c}10,2 \\
17\end{array}$ & $\begin{array}{c}0,9 \\
8\end{array}$ & $\begin{array}{l}3,8 \\
10\end{array}$ & $\begin{array}{l}7,3 \\
17\end{array}$ & $\begin{array}{c}10,8 \\
18\end{array}$ & $\begin{array}{c}11,9 \\
25\end{array}$ & $\begin{array}{c}3,0 \\
8\end{array}$ & _- & $\begin{array}{c}0,1 \\
2\end{array}$ & $\begin{array}{c}1,3 \\
5\end{array}$ & $\begin{array}{c}3,5 \\
17\end{array}$ & $\begin{array}{c}2,8 \\
11\end{array}$ & $\begin{array}{c}0,1 \\
1\end{array}$ \\
\hline
\end{tabular}



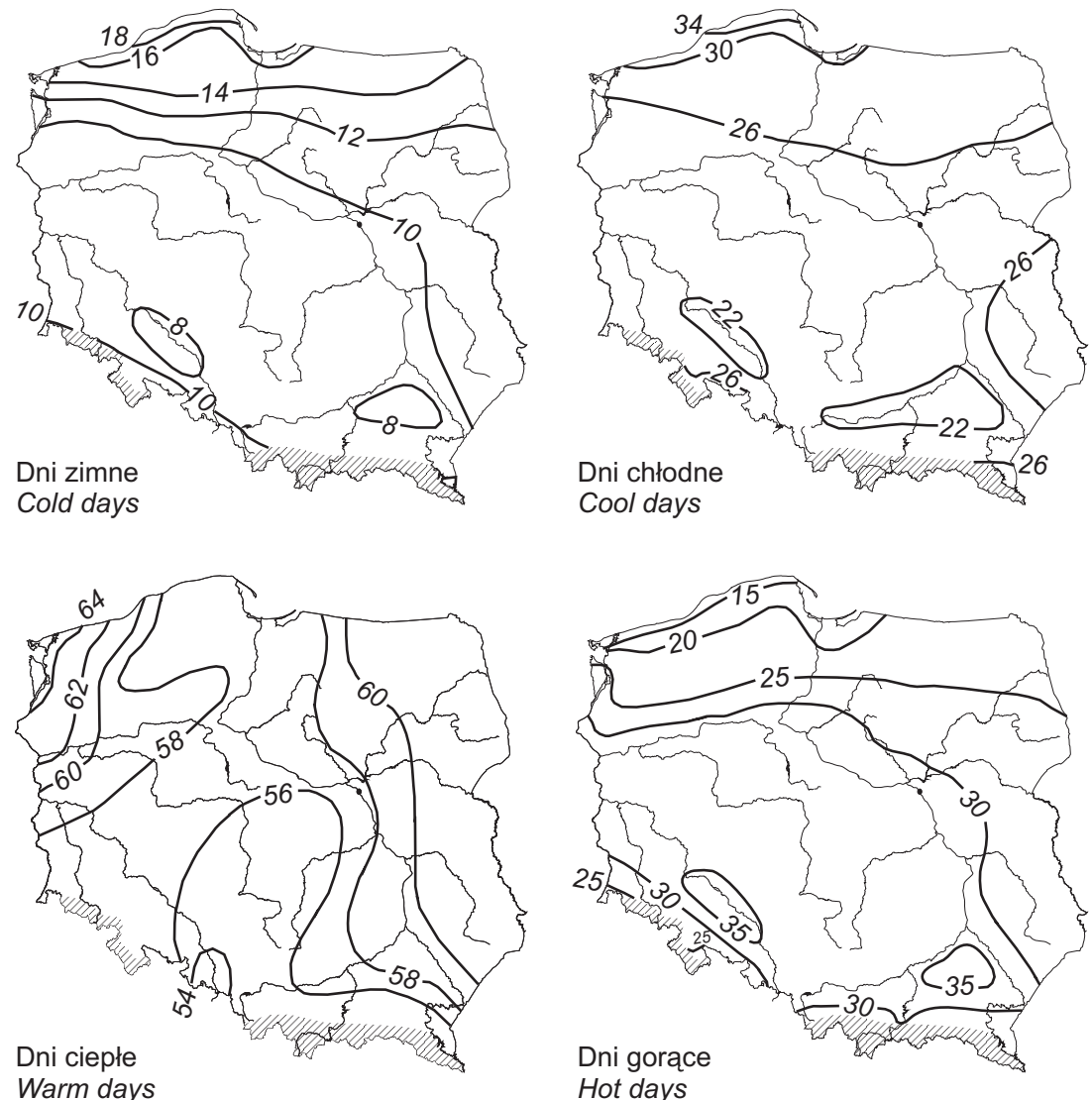

\section{Hot days}

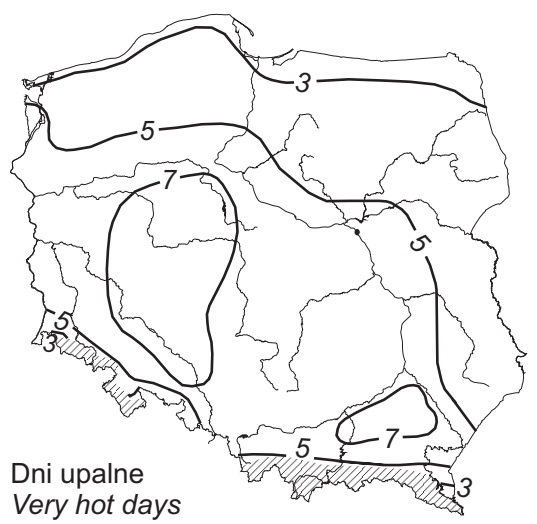

Ryc. 2. Średnia liczba dni zimnych, chłodnych, ciepłych, gorących i upalnych w okresie IV-IX, 1986-2009

The mean numbers of cold, cool, warm, hot and very hot days in the April-September period of years 1986-2009 

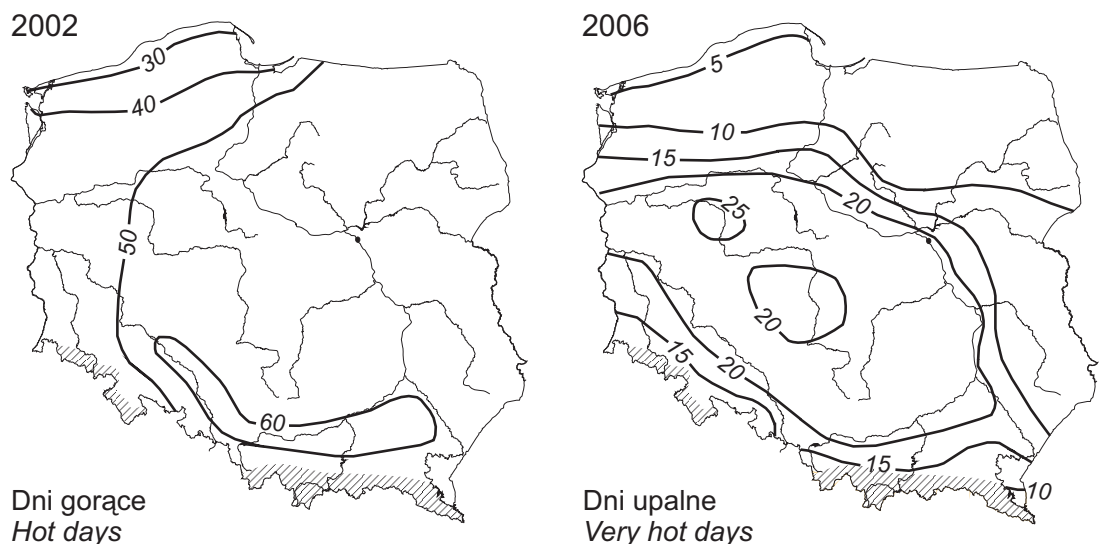

Ryc. 3. Liczba dni gorących w 2002 i dni upalnych w 2006 r.

The numbers of hot days in 2002 and very hot days in 2006

nawet 25, przewyższając liczbę dni upalnych w całym 55-leciu (1951-2005), rozpatrywanym przez E. Cebulak i D. Limanówkę (2007). Mniej dotknięta upałami była północna część kraju - poniżej 10, a nad samym morzem liczba dni nie przekroczyła w tym roku 5 (ryc. 3).

Dni upalne najwcześniej wiosną pojawiały się w pierwszej dekadzie maja w południowo-zachodniej części Polski oraz w górnym odcinku Wisły. Na wschodzie oraz w rejonach podgórskich pierwsze daty pojawiania się dni upalnych przypadały na trzecią dekadę maja, a na północy kraju - na pierwszą dekadę czerwca (ryc. 4). Najpóźniej latem dni upalne występowały jeszcze po 15 września w centralnej części Wielkopolski i w Kotlinie Sandomierskiej, zaś w północno-wschodniej części kraju w ostatniej pentadzie sierpnia. Coraz częściej pojawiają się dni upalne, w których nocą notuje się minimalną temperaturę powietrza $\geq 20,0^{\circ} \mathrm{C}$, co jest bardzo uciążliwe dla organizmu człowieka. Frekwencja lat z takimi nocami wyniosła w okresie 1986-2009 od 1-3 w części północnej do 6-8 w południowo-zachodniej części kraju. Bardzo dużo takich nocy gorących wystąpiło w Europie podczas fali upałów w 2003 r., a w 2006 szczególnie w Europie Środkowej (Twardosz, 2009). Według K. Piotrowicz (2007) główną przyczyną pojawiania się nocy gorących w Krakowie są kierunek adwekcji i napływ zwrotnikowych i polarno-kontynentalnych mas powietrza.

W Polsce największe nasilenie ruchu turystycznego notuje się w okresie czerwiec-sierpień, szczególnie na wybrzeżu Bałtyku i w górach oraz na Pojezierzu Pomorskim i Pojezierzu Mazurskim (Lijewski i inni, 2002). W związku z tym opracowano procentowy udział dni charakterystycznych w ogólnej liczbie dni od czerwca do sierpnia właśnie dla tego okresu. Najczęściej występują dni ciepłe - od 32\% na Dolnym Śląsku do 44\% na obydwu Pojezierzach i ponad 48\% 

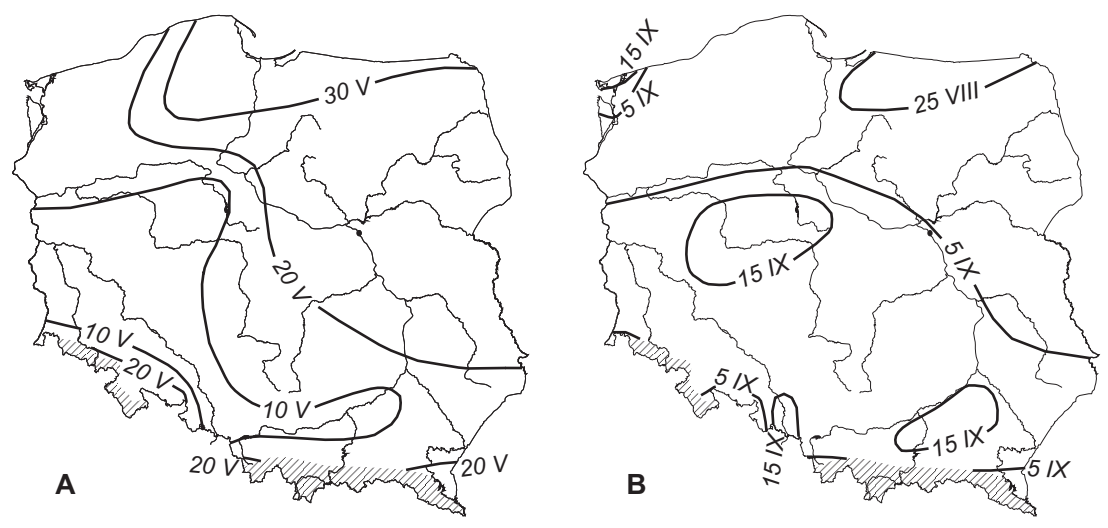

Ryc. 4. Najwcześniejsze wiosną (A) i najpóźniejsze latem (B) daty występowania dni upalnych $\left(t_{\max }>30^{\circ} \mathrm{C}\right)$ w latach $1986-2009$

The earliest spring (A) and latest summer (B) dates of occurrence of very hot days $\left(t_{\max }>30^{\circ} \mathrm{C}\right)$ in the years $1986-2009$

w zachodniej części wybrzeża Bałtyku (ryc. 5). Znacznie mniejszy udział mają dni gorące - od 12\% na wybrzeżu (od Ustki po Hel) do 32\% na Nizinie Śląskiej i w Kotlinie Sandomierskiej. Dni upalne zdarzają się rzadko - od 2-3 \% na północy kraju do ponad 8\% w rejonie Wrocławia i Opola. Odwrotny do wyżej opisanego przestrzenny rozkład wykazują dni chłodne, których udział kształtuje się od 2\% w rejonie Poznania i Wrocławia oraz Sandomierza i Rzeszowa do ponad 6\% w północnej części wybrzeża Bałtyku (ryc. 5). Spośród opisywanych obszarów kraju, Pomorze wyróżnia się największym przestrzennym gradientem udziału dni charakterystycznych w ogólnej liczbie dni w okresie od czerwca do sierpnia.

$\mathrm{Na}$ rycinie 6 przedstawiono procentowy udział dni charakterystycznych w całym półroczu ciepłym dla 8 wybranych stacji meteorologicznych reprezentujących różne regiony klimatyczne kraju. Procentowy udział dni zimnych i chłodnych w ogólnej liczbie dni maleje w miarę przemieszczania się z północy na południe, wzrasta zaś udział dni gorących. Dni upalnych najwięcej jest w południowo-zachodniej części kraju, zaś najmniejszą zmienność występowania dni charakterystycznych między stacjami wykazują dni ciepłe - od 30\% w Opolu do 33\% w Suwałkach. Udział pozostałych (nieanalizowanych w pracy) dni półrocza ciepłego, w których maksymalne temperatury powietrza zawierały się w przedziałach $15,1-18,0{ }^{\circ} \mathrm{C}$ i $23,1-25,0{ }^{\circ} \mathrm{C}$, wahał się od $28 \%$ w Opolu i Rzeszowie do 33\% w Szczecinku (ryc. 6).

Z analizy maksymalnej temperatury powietrza $25,1-30,0{ }^{\circ} \mathrm{C}$ i powyżej $30,0^{\circ} \mathrm{C}$ w kolejnych dniach od kwietnia do września wynika, że dni gorące najczęściej występowały od 26 czerwca do 25 sierpnia, a upalne od 15 lipca do 20 sierpnia. Te ostatnie notowano głównie jako pojedyncze dni (zwłaszcza na wybrzeżu Bał- 

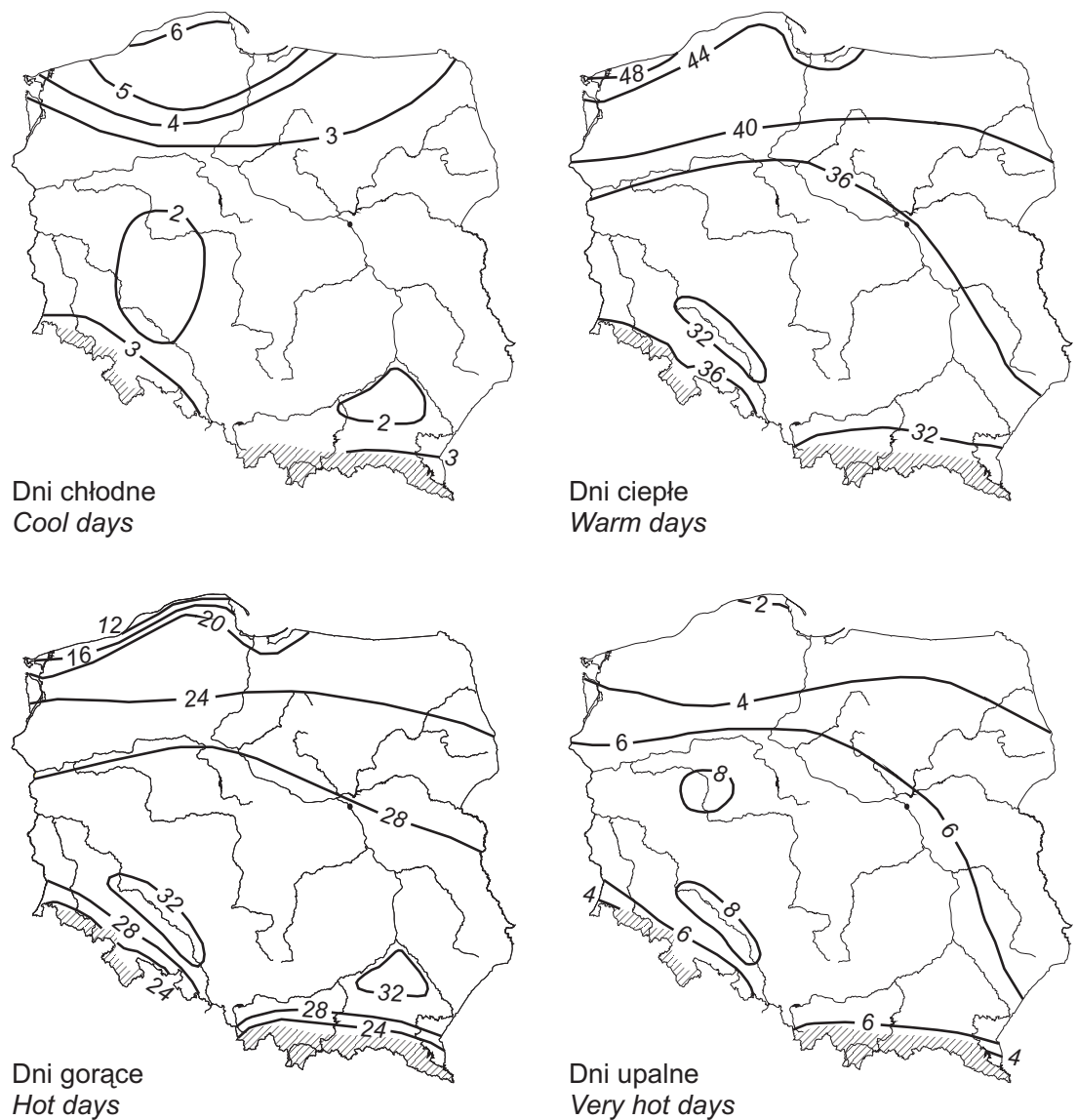

Hot days

Very hot days

Ryc. 5. Procentowy udział dni chłodnych, ciepłych, gorących i upalnych w stosunku do ogólnej liczby dni lata (VI-VIII). Lata 1986-2009

The percentage contribution among all summer (June-August) days in the years 1986-2009 made by days classed as cool, warm, hot and very hot

tyku) lub w ciągach 2-dniowych. Razem stanowią one ponad 50\% ogólnej liczby dni upalnych od czerwca do sierpnia. Fale upałów $\left(t_{\max }>30,0^{\circ} \mathrm{C}\right)$ trwające 3 i więcej dni pojawiały się w lecie z reguły w centralnej i południowej części kraju, z częstością od 14 do 18, a lokalnie nawet 20 przypadków, a bardzo rzadko w strefie wybrzeża - około 2 przypadki. Dni upalne cechuje większe zróżnicowanie pod względem przestrzennego występowania aniżeli pod względem wysokości temperatury powietrza. Na przykład przeciętna (1986-2009) intensywność dni upalnych w czerwcu wyniosła w Suwałkach 31,0 , a w Poznaniu $32,0^{\circ} \mathrm{C}$. Jeszcze mniejsze różnice miały miejsce w lipcu i sierpniu - odpowiednio $31,8^{\circ} \mathrm{C} \mathrm{i} 31,7^{\circ} \mathrm{C}$ 


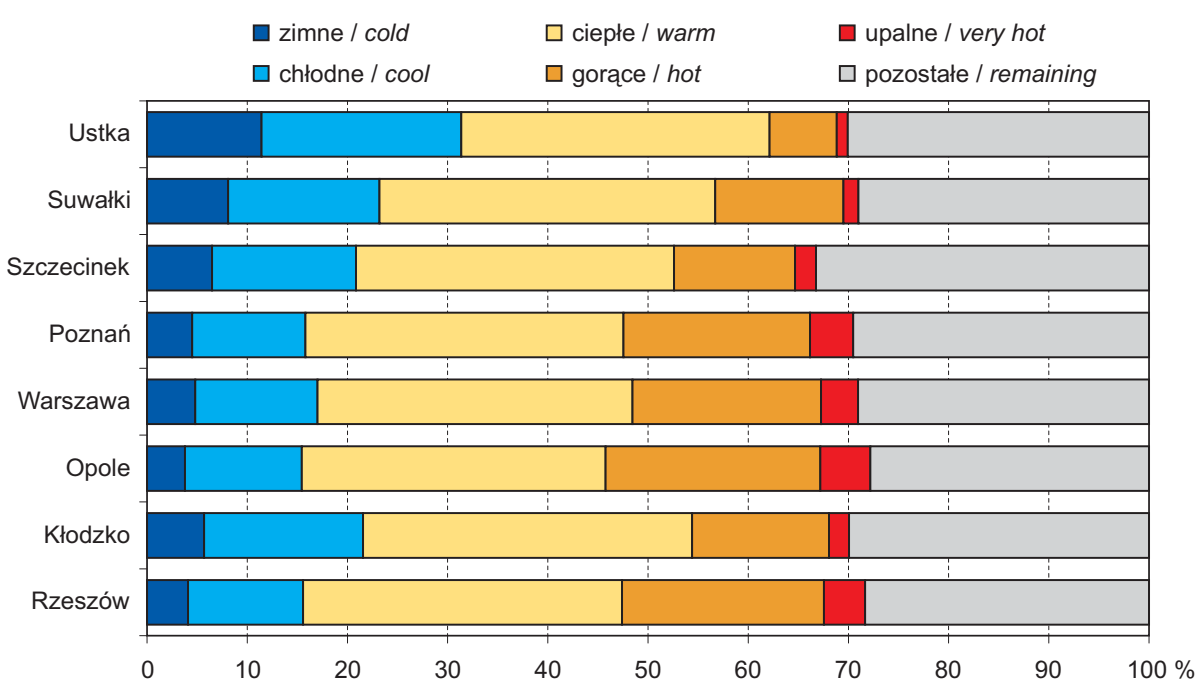

Ryc. 6. Procentowy udział dni charakterystycznych w stosunku do ogólnej liczby dni w okresie kwiecień-wrzesień. Lata 1986-2009

The percentage contribution among all warm half-year (April-September) days in the years 1986-2009 made by days assigned to the different thermal categories

oraz 32,0 i $31,9^{\circ} \mathrm{C}$. W okresie 24 badanych lat 7-dniowe i dłuższe fale upałów zdarzały się już bardzo rzadko, od 1 do 3 przypadków (tab. 2). W 1994 r. wystąpiły 16-dniowe upały, np. w Rzeszowie - od 24 lipca do 8 sierpnia, a 14-dniowe, jak np. w Lublinie, od 25 lipca do 7 sierpnia. W 2006 r. w Opolu od 18-30 lipca podczas fali upałów średnia dobowa temperatura powietrza wyniosła $25^{\circ} \mathrm{C}$.

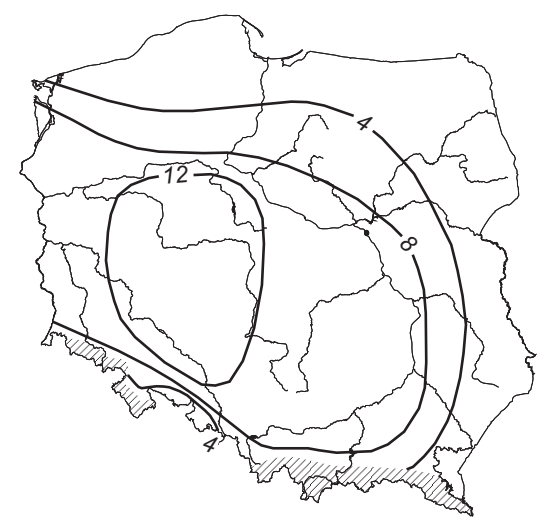

Ryc. 7. Ogólna liczba dni z temperaturą maksymalną $\geq 35^{\circ} \mathrm{C}$ w latach 1986-2009

Total numbers of days in the years $1986-2009$ with maximum temperature $\geq 35^{\circ} \mathrm{C}$ 
Tabela 2. Liczba sekwencji dni upalnych trwających: 2, 3, 4, 5, 6, 7 i >7 dni w okresie czerwiec-sierpień, 1986-2009

Numbers of 2-, 3-, 4-, 5-, 6-, 7- or >7-day periods in the very hot category, June-August in the years 1986-2009

\begin{tabular}{|l|r|r|r|r|r|r|r|c|}
\hline \multirow{2}{*}{\multicolumn{1}{c}{ Stacja }} & \multicolumn{6}{c}{ Sekwencje 2 - i więcej -dniowe / Sequences of 2 and more days } \\
\cline { 2 - 8 } & \multicolumn{1}{c}{2} & 3 & 4 & 5 & 6 & 7 & $>7$ & Ogółem / Total \\
\hline Białystok & 15 & 3 & 1 & 1 & - & 1 & 1 & 22 \\
Chojnice & 12 & 1 & 2 & - & - & - & 1 & 16 \\
Gorzów Wlkp. & 17 & 9 & 2 & 1 & - & - & 2 & 31 \\
Kalisz & 23 & 10 & 1 & 2 & - & - & 1 & 40 \\
Kielce & 19 & 5 & 2 & 1 & - & - & 2 & 29 \\
Kłodzko & 10 & 4 & 1 & 1 & - & - & 1 & 17 \\
Koło & 20 & 9 & 3 & 1 & - & 2 & 1 & 36 \\
Kołobrzeg & 7 & 2 & - & - & - & - & - & 9 \\
Kraków & 18 & 8 & 2 & - & 3 & 1 & 1 & 33 \\
Lublin & 13 & 7 & - & - & - & 1 & 1 & 22 \\
Eódź & 24 & 7 & 3 & 1 & - & - & 3 & 38 \\
Mława & 16 & 8 & - & - & 1 & - & 1 & 26 \\
Nowy Sącz & 21 & 12 & 5 & - & 1 & - & 1 & 40 \\
Olsztyn & 15 & 4 & 2 & 1 & 2 & - & 1 & 24 \\
Opole & 24 & 16 & 3 & 2 & - & 1 & 2 & 48 \\
Poznań & 26 & 12 & 2 & 1 & - & - & 3 & 44 \\
Rzeszów & 17 & 13 & 3 & 1 & - & 1 & 2 & 37 \\
Siedlce & 17 & 8 & 3 & - & - & 1 & 1 & 30 \\
Suwałki & 10 & 1 & - & 1 & 1 & 1 & - & 14 \\
Szczecin & 17 & 5 & 2 & - & - & - & 2 & 26 \\
Świnoujście & 7 & 1 & - & - & - & - & - & 8 \\
Toruń & 19 & 15 & 2 & 1 & - & - & 2 & 39 \\
Ustka & 3 & 2 & - & - & - & - & - & 5 \\
Warszawa & 20 & 11 & 4 & 2 & 1 & - & 2 & 40 \\
Wrocław & 24 & 9 & 2 & 1 & 2 & - & 2 & 40 \\
Zielona Góra & 17 & 8 & 2 & 1 & - & - & 2 & 30 \\
\hline
\end{tabular}

M. Kuchcik (2006), posługując się temperaturą pozorną stwierdziła, że fale upałów w Polsce mogą trwać od 6 do 21 dni. W czasie występowania upałów notuje się także temperaturę maksymalną $\geq 35,0^{\circ} \mathrm{C}$ (ryc. 7). Największa uciążliwość dla organizmu człowieka z tytułu pojawiania się tak wysokiej temperatury miała miejsce w środkowej części kraju, gdzie zanotowano ponad 12 przypadków, a w rejonie Opola nawet 16. W północnej i wschodniej części kraju wystąpiło 
od 1 do 4 przypadków. Absolutnie najwyższa maksymalna temperatura powietrza w badanym okresie wyniosła $39,6^{\circ} \mathrm{C}$ na stacji w Rzeszowie w dniu 17 sierpnia $1989 \mathrm{r}$.

Przeprowadzona analiza częstości występowania i czasu trwania dni upalnych dała podstawę do wydzielenia na obszarze kraju trzech stref uciążliwości (ryc. 8).

Strefa I - o małej uciążliwości, obejmuje północną część Polski, gdzie co najmniej trzydniowe fale upałów pojawiają się raz na 10 lat na wybrzeżu i dwa razy na 10 lat w pozostałej części tej strefy;

Strefa II - o średniej uciążliwości, obejmuje południową część Pomorza, Pojezierze Mazurskie i wschodnią część Polski oraz Pogórze Karpackie i Przedgórze Sudeckie; fale upałów notowane są tu od 3 do 6 razy na 10 lat;

Strefa III - o dużej uciążliwości, zajmuje środkową i południowo-zachodnią część kraju, gdzie trzydniowe i dłuższe fale upałów występują w 6-8 latach na 10. W strefie tej mogą pojawiać się upały trwające nawet 10 i więcej dni. Najwyższa temperatura podczas trwania fali upałów może przekroczyć $35,0^{\circ} \mathrm{C}$.

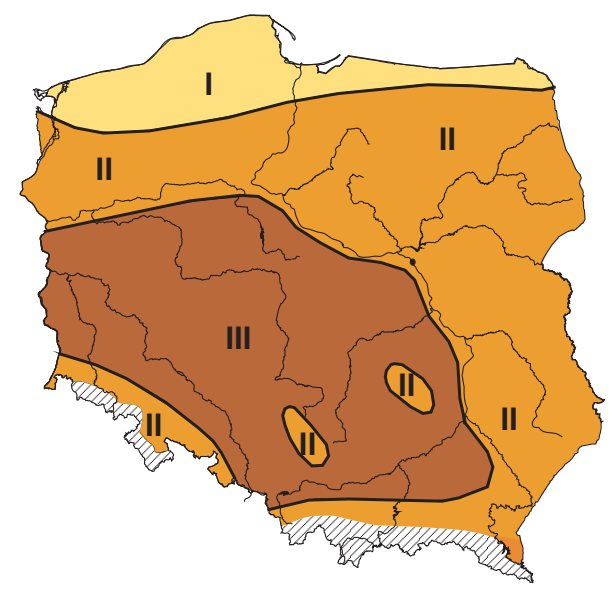

Uciążliwość:

Burden:

$\square$ mała / small

$\square$ średnia / medium

duża / great

Ryc. 8. Strefy uciążliwości z tytułu występowania fal upałów trwających co najmniej 3 dni

Zones deemed to have burdensome weather on account of the occurrence there of heatwaves of at least 3 days' duration

\section{Podsumowanie}

W półroczu ciepłym (IV-IX) stwierdzono dodatni, wysoce istotny statystycznie $\mathrm{w}$ południowej i zachodniej części kraju, a na pozostałym obszarze istotny trend liczby dni gorących $\left(t_{\max } 25,1-30,0{ }^{\circ} \mathrm{C}\right)$. Liczba dni zimnych $\left(t_{\max } \leq 10,0^{\circ} \mathrm{C}\right)$ wykazuje w północnej i środkowej części kraju wysoce istotny 
trend ujemny, a w południowo-wschodniej - tylko istotny, zaś liczba dni chłodnych $\left(t_{\max } 10,1-15,0^{\circ} \mathrm{C}\right)$ zmniejsza się istotnie $\mathrm{w}$ południowych i zachodnich rejonach kraju. Nie stwierdzono wyraźnych zmian liczby dni ciepłych i upalnych. W badanych latach 1986-2009 dni upalne $\left(t_{\max }>30,0^{\circ} \mathrm{C}\right)$ najwcześniej pojawiały się w pierwszej dekadzie maja, a pod koniec lata występowały jeszcze w drugiej dekadzie września.

Spośród pięciu rozpatrywanych przedziałów maksymalnej temperatury powietrza, w okresie od kwietnia do września najczęściej notowano dni ciepłe - średnio od około 54 do 64, a następnie dni gorące - od około 15 do 35, przy dużym przestrzennym ich zróżnicowaniu na Pomorzu. Najrzadziej notowano dni upalne - średnio od 3 do 7, przy czym w niektórych latach $(1994,2006)$ ich maksymalna liczba wynosiła od 23 do 26. Dni zimnych występuje na terenie kraju średnio od 8 do 18, głównie w kwietniu, a w strefie wybrzeża również w maju. W porównaniu do dni zimnych, dni chłodnych notuje się 2-3 razy więcej. Latem duży udział dni ciepłych w ogólnej liczbie dni stwarza dobre warunki do rekreacji i turystyki na Pojezierzu Pomorskim i Pojezierzu Mazurskim (od 40 do 44\%) oraz na wybrzeżu (od 45 do 50\%), a mniej dogodne - w środkowej i południowo-zachodniej części kraju (poniżej 36\%). Na tych ostatnich obszarach czynnikiem ograniczającym wypoczynek i pracę na otwartej przestrzeni mogą być dni gorące, których udział wynosi od 28 do około 32\%, zwłaszcza, gdy w tych dniach ma miejsce intensywne napromieniowanie. Dni upalne są uciążliwe dla organizmu człowieka w środkowo-zachodniej części kraju, gdzie ich udział wynosi od 6 do około 8\%, a w strefie wybrzeża 2-3 \%. W półroczu ciepłym dni gorące najczęściej występują od 26 czerwca do 25 sierpnia, a upalne od 15 lipca do 20 sierpnia.

Z uwagi na częstość trzydniowych i dłuższych fal upałów oraz procentowy udział dni upalnych w ogólnej liczbie dni w okresie czerwiec-sierpień, wydzielono na terenie kraju 3 strefy uciążliwości dla organizmu człowieka - od małej do dużej.

W świetle uzyskanych wyników stwierdza się polepszanie warunków termicznych do rekreacji w półroczu ciepłym na wybrzeżu oraz na Pojezierzu Pomorskim i Pojezierzu Mazurskim, a wzrost uciążliwości - w środkowozachodniej i południowej części kraju.

\section{Piśmiennictwo}

Błażejczyk K., 2004, Bioklimatyczne uwarunkowania rekreacji i turystyki w Polsce, Prace Geograficzne, IGiPZ PAN, 192, Warszawa.

Bogucki J., Dąbrowska A., Tyczka S., Wnuk B., 1999, Biometeorologia turystyki i rekreacji, Seria: Podręczniki, 48, AWF, Poznań.

Boksa V.G., Boguckij B.V., 1966, Klimatoterapia (rukovodstvo dla vracej), Izd. Zdorove, Kiev. 
Brazdil R., Budikova., Auer I., Bohm R., Cegnar T., Fasko P., Lapin M., Gajic-Capka M., Zaninovic K., Kolewa K., Niedźwiedź T., Ustrnul Z., Szalai S., Weber R.O., 1996, Trends of maximum and minimum daily temperatures in central and southeastern Europe, International Journal of Climatology, 16, s. 765-782.

Brunetti M., Bufoni L., Mangeri M., Nanni T., 2000, Trends of minimum and maximum daily temperatures in Italy from 1865 to 1996, Theoretical and Applied Climatology, 16, s. 765-782.

Cebulak E., Limanówka D., 2007, Dni z ekstremalnymi temperaturami powietrza, [w:] K. Piotrowicz, R. Twardosz (red.), Wahania klimatu w różnych skalach przestrzennych $i$ czasowych, Instytut Geografii i Gospodarki Przestrzennej, UJ, Kraków, s. $185-194$.

Cegnar T., Matzarakis A., 2004, Trends of thermal bioclimate and their aplication for tourism in Slovenia, [w:] Matzarakis A., De Freitas C.R., Scott D. (red.) Advances in Tourism Climatology, Berichte des Meteorologischen Institutes der Universtat Freiburg, 12, s. 66-73.

Kossowska-Cezak D., Martyn D., Olszewski K., Kopacz-Lembowicz M., 2000, Meteorologia i klimatologia. Pomiary, obserwacje, opracowania, Wydawnictwo Naukowe PWN, Warszawa-€ódź.

Kozłowska-Szczęsna T., Krawczyk B., Kuchcik M., 2004, Wpływ środowiska atmosferycznego na zdrowie i samopoczucie człowieka, Monografie IGiPZ PAN, 4, Warszawa.

Koźmiński C., Michalska B., 2010, Zmienność liczby dni goracych i upalnych oraz odczucia cieplne w strefie polskiego wybrzeża Battyku, Acta Agrophysica PAN, Lublin, 15, 2, s. 347-358.

-, 2005, Ustonecznienie w Polsce, AR w Szczecinie, Uniwersytet Szczeciński, Szczecin.

Kuchcik M., 2006, Fale upatów w Polsce w latach 1993-2002, Przegląd Geograficzny, 78, 3, s. 397-412.

Lijewski T., Mikołowski B., Wyrzykowski J., 2002, Geografia turystyki Polski, PWE, Warszawa.

Matzarakis A., Mayer H., 1991, The extreme heat wave in Athens in July 1987 from the point of view of human biometeorology, Atmospheric Environment, 25B, 2, s. 203-211.

Michalska B., Mąkosza A., 2007, Warunki biotermiczne na Nizinie Szczecinskiej podczas lata w roku 2006 na tle sezonów letnich 1961-1990 i 2001-2005, Balneologia Polska, 3 (109), s. 186-194.

Piotrowicz K., 2007, Wieloletnie zróżnicowanie liczby nocy goracych w Krakowie, Wahania klimatu w różnych skalach przestrzennych i czasowych, Instytut Geografii i Gospodarki Przestrzennej, UJ, Kraków, s. 279-286.

Twardosz R., 2009, Fale niezwyktych upatów w Europie na początku XXI wieku, Balneologia Polska, 3 (117).

Ustrnul Z., Czekierda D., 2002, Ekstremalne wartości temperatury powietrza w Polsce w drugiej połowie XX wieku na tle warunków cyrkulacyjnych, Wiadomości IMGWWarszawa, 25, 4, s. 3-21.

[Wpłynęło: czerwiec; poprawiono: listopad 2010 r.] 


\title{
CZESŁAW KOŹMIŃSKI, BOŻENA MICHALSKA
}

\author{
VARIABILITY IN THE NUMBERS OF COLD, COOL, WARM, HOT, \\ AND VERY HOT DAYS IN POLAND IN THE APRIL-SEPTEMBER PERIOD
}

The work described here referred to maximum 24-hour air temperatures in the warm (April-September) half-years of years 1986-2009 inclusive, as recorded at 38 meteorological stations of Poland's Institute of Meteorology and Water Management (IMGW). On the basis of their temperatures, days in the above period were categorised as cold $\left(t_{\max } \leq 10.0^{\circ} \mathrm{C}\right)$, cool $\left(t_{\max } 10.1-15.0^{\circ} \mathrm{C}\right)$, warm $\left(t_{\max } 18.1-23.0^{\circ} \mathrm{C}\right)$, hot $\left(t_{\max } 25.1-30.0^{\circ} \mathrm{C}\right)$ or very hot $\left(t_{\max }>30.0^{\circ} \mathrm{C}\right)$, and calculations were then made of the mean and maximum numbers of such days in warm half-year periods and summers (June-August inclusive). The earliest and latest dates of occurrence of very hot days were noted, as were incidences of heatwaves, i.e. periods of 2 or more consecutive days in the very hot category. A search was further made for instances of heatwaves defined in this way coinciding with minimum temperatures of $\geq 20,0^{\circ} \mathrm{C}$, since this circumstance has a marked effect in making heatwaves still more burdensome. Days assigned to the different categories were assessed spatially, as well as temporally, zones capable of generating weather particularly burdensome for the human organism being identified by reference to the prevalence of three-day or longer heatwaves, as well as the percentage of all summer days assignable to the "very hot" category.

thermal characterisation of days, trends, temporal and spatial break down of data, heatwaves, burdens imposed by weatherThe material for the study took the form of data on maximum 24-hour air temperatures in the warm (April-September) half-year, as gathered over the period 1986-2009 at 38 of the weather stations run by Poland's Institute of Meteorology and Water Management (IMGW). The numbers of days characteristic of different descriptions were noted with cold implying $t_{\max } \leq 10.0^{\circ} \mathrm{C}$, cool $\left(t_{\max } 10.1-15.0^{\circ} \mathrm{C}\right)$, warm $\left(t_{\max } 18.1-23.0^{\circ} \mathrm{C}\right)$, hot $\left(25.1-30^{\circ} \mathrm{C}\right)$ and very hot $\left(t_{\max }>30.0^{\circ} \mathrm{C}\right)$. Mean and maximum numbers of such days were determined, along with any possible trends across the multiannual period, and contributions made by the different categories in relation to the total number of days in summer (June-August) and in the entire warm half-year (April-September). In the case of very hot days, the earliest dates of occurrence in spring and the latest in summer were identified, as were sequences of days of different durations and incidences with minimum temperature $\geq 20.0^{\circ} \mathrm{C}$ (since such circumstances increase the burdensome nature of heatwaves). Where the warm half-year as a whole was concerned, the southern and western parts of Poland have been subject to a positive trend for hot days $\left(t_{\max } 25.1-30.0^{\circ} \mathrm{C}\right)$ that can be regarded as highly significant statistically. The corresponding trend noted for the rest of the country achieved "significant" status. In turn, numbers of cold days $\left(t_{\max } \leq 10.0^{\circ} \mathrm{C}\right)$ are characterised by a negative trend that proves highly significant for northern and central parts, and significant for the south-east. Where numbers of cool days $\left(t_{\max } 10.1-15.0^{\circ} \mathrm{C}\right)$ are concerned, there has been a significant decrease in the south and west. No distinct changes for numbers of warm or very hot days were to be observed. Over the analysed (1986-2009) period, very hot days $\left(t_{\max }>30.0^{\circ} \mathrm{C}\right)$ appeared at the earliest in the first third of May and at the latest in the second third of September. 
Among the five discussed categories or intervals for maximum air temperature in the April-September period, it was warm days that were observed most frequently on average from 54 to 64 times, as followed by hot days, of which there are some 15 to 35 (differences being particularly marked in the Pomerania region). Very hot days were recorded least frequently - on average just 3 to 7 times, though there were some years $(1994,2006)$ in which maximum numbers ranged from 23 to 26 days. Cold days occur nationwide some 8-18 times in the warm half-year, though primarily just in April, though also in May along the coast. Days in the different categories were thus assessed from both the temporal and spatial points of view.

Analysis of the frequency of occurrence of heatwaves lasting three days or more and on percentage contributions to the total number of days in summer offered a basis for identifying three zones across Poland in which weather could be considered burdensome to the human organism.

Overall, the results obtained imply improved (improving) thermal conditions for recreation in the warm half-year along the Polish coast and in the Pomeranian and Mazurian Lakelands. On the more negative side, heat has been becoming more burdensome in the west central and southern parts of Poland. 
http://rcin.org.pl 